Special Issue 特集論文

Invited Peer-Reviewed Article 招待査読論文

\title{
Externality of Retailing and Regional Contribution 小売業の外部性と地域貢献
}

\begin{abstract}
Takemasa Ishihara*1
大阪市立大学 名誉教授

石原 武政

${ }^{* 1}$ Professor Emeritus at Osaka City University, take-ishihara@kra.biglobe.ne.jp

Abstract : The regional contributions of retailers are gaining a lot of attention, and this is by no means an "unnecessary task unrelated to the original work" of the retailer. Rather, it is a legitimate assessment of externality that the store-type retailer originally had. Consideration of externalities and the main retail business, which has been both sides of the same coin, have been separated with development of chain store operations. External regulation, including that by the local government, was a step toward a new norm for retailers. Chain-type retailers are also working on a number of community contribution activities, but it is important to tackle "town development" together with local retailers, and not with companies alone.
\end{abstract}

Keyword : Externality of retailing, Regional contribution, Internal norms, External regulation

要約 : 小売業の地域貢献に多くの注目が集まっている。それは決して小売業の「本来的業務と無関係な余計な業務」ではない。 むしろ, 店舗型の小売業が本来的のもっていた外部性への正当な評価にほかならない。かつては外部性への配慮は本業と不可分 に結びついていたが, チェーン店の登場によってその両者が分離した。外部からの規制はそれを新たな規範として形成するため の1つのステップであった。チェーン型の小売業も多くの地域貢献活動に取り組んでいるが, 企業単独ではなく, 地域の小売業 と共に「まちづくり」に取り組むことが強く求められている。

キーワード：小売業の外部性，地域貢献，内的規範，外的規制

Information : Received 11 September 2018; Accepted 15 October 2018

\section{I.はじめに}

地域商業政策は流通効率化政策と共に流通政策の中で 一貫して主要な柱を構成してきた。それは時に流通効率 化政策に押されながらも，しかし確実に政策の柱であり 続けた 1$)$ 。私達は今, 市場における自由な競争は流通効 率化をもたらすと，ほとんど無条件に信じている。しか し, 戦前から戦後の 1980 年代半ばころまで, それは決 して無条件に信じられることではなかった。競争は取引 相手に対するサービスを競い合う側面をもつが，それは 必ずしも効率化とは結び付かず, 結果からみれば非効率 な取引慣行に基づくサービスの継続をもたらすことも あったからである。実際, コンピュータの導入に伴って 情報化が急速に進展したときには, そうした状況は決し

\section{て珍しくはなかった。}

そんな時期には, 流通政策は流通効率化において重要 な役割を果たした ${ }^{2)}$ 。特に, 流通は生産性が低く，その 非効率性が長年にわたって指摘されてきただけに, 流通 の効率化を促進することは最大の課題であったし, その ためには流通政策がそれを強力に推し進める必要があっ た。実際，戦後の本格的な流通政策の始まりとされるさ れるのは, 1964（昭和 39）年に通商産業大臣が設置され たばかりの産業構造審議会流通部会に行った諮問である が, それは「流通機構の近代のために, いかなる対策が 必要か」というものだったのである。

しかし, その後, 流通過程における競争環境が変化し, 取引相手に対するサービスが経済的取引として行われる ようになると，競争は次第に流通の効率化を導くように なる。市場における競争が効率化をもたらすわけで，そ 
うなれば政府がことさらに効率化政策を推進する必要は 低くなり，それに代わって地域商業政策への関心が高ま ることになる。近年の地域商業政策への関心の高まりは こうした事情を強く反映している。

そのようにいえば，地域商業政策は流通効率化政策の 陰に隠れていたかのようにも見える。しかし，実際にそ うだったわけでは決してない。通商産業省の政策ではな いためにあまり注目されることはなかったが，例えば 1952（昭和 27）年に施行された耐火建築促進法は都市の 不燃化を掲げ，商店街のハード面からの「近代化」を強 力に推し進めた。それは 1961（昭和 36）年の防災建築 街区造成法を経て，1969（昭和 44）年の都市再開発法に つながっていった。それらは間違いなく都市の中心部に おける商店街の改造にほかならなかった。以来，ハード 面からの商店街整備は流通政策の中で中心的な柱であり 続けた。

それだけではない。近年でこそネット通販が伸長して きているとはいうものの, 商業は常に店舗商業として物 理的な店舗を通して営まれてきたし，店舗商業はほとん どの場合集積を形成し，その必然的な結果として外部に まちをつくってきた。単に物理的な街並みを形成したと いうだけではなく，地域の伝統・文化を継承するのに重 要な役割を果たすと共に，まちの䨌囲気を演出し，コミュ ニティの形成に貢献してきた。私はこれを「小売業の外 部性」と呼んできたが3)，地域商業政策はこうした外部 性を正当に評価しようとするものにほかならない。

流通は広い意味での経済システムの中で理解される限 り，生産と消費との間の懸隔を架橋することに意義があ り，したがってその効率的な架橋こそが本質的機能だと されてきた。もとより，そのことに疑問をさしはさむ余 地はないのだが，商業は決して「本質的機能」のみを遂 行してきたわけではない。商業は懸隔の架橋にかかって 「副次的」とされたさまざまな機能を遂行してきた。それ だけではない。とりわけ，商業集積を形成する店舗型の 小売業は，地域の人びととふれあい，地域の人びとを顧 客として迎え入れ，商品を提供するという以外のさまざ まな側面からも，彼らの生活を支えてきたのである。

近年ではインターネットを活用した無店舗販売が大き く支持を伸ばす中で, 郊外に展開するショッピングセン
ターには陰りが見え始めたようだが，各種の専門量販店 は堅調な伸びを示す一方，コンビニエンスストアもまた ますますその利便性を強調することによって，1つの店 舖で従来型の業種店, 数店舗に代替している。こうした 流れを推進するのは流通効率化を求める動きであり，こ の観点からみれば，その中から確実に新しい「業態」が 開発されつつあるといってよい。しかし，それによって 従来型の小売業が姿を消すとなれば，彼らが果たしてき た外部性も同時に失われていかざるを得ず，それを補完 する別の形での外部性が求められることになる。小売業 の進化・代替は流通効率化の観点からだけではなく, 小 売業が果たしてきた外部性の観点からも評価される必要 がある。

ここで外部性として評価しようとするのは, 商業, 特 に小売業の活動の結果であることに間違いにもかかわら ず，従来の流通論の中ではほとんどまったくといってよ いほど考慮されることはなかった側面である。そうした 見方からすれば，地域商業政策として小売業のさまざま な取り組みを評価することは，小売業にまったく非本質 的な役割を期待することになり，「なぜ，小売業は自分の 商売を犠牲にしてまで，そうした余計な業務に取り組ま なければならないのか」「小売業は消費者により良いもの をより安く提供するという本来の業務に専念すべきでは ないのか」といった声が聞こえてくる。

しかし，地域商業政策が焦点を当てようとするのは， 小売業にとってもともと無関係な役割では決してない。 特に店舖型の小売業は，理論がそれをどのように位置づ けるかにかかわりなく，ここで外部性と呼んだ役割を果 たしてきた。確かに，それらは市場において取引の対象 となってはいない。しかし，それは「市場」という評価 システムの特性によるのであって，小売業の果たす役割 そのものとはかかわりのないことである。小売業が果た す役割を正しく理解しようとすれば，本質的機能や経済 的機能だけに着目するのではなく，小売業の活動をその まま, ありのままに理解する必要がある。

本稿の課題は, こうした問題意識に立って, 小売業の 外部性について, やや具体的に考察し, その観点から地 域商業政策の意味を問うことにある。 


\section{II. 大型店の社会的責任を求める地域の声}

今日，小売企業の社会的責任について，「それは企業の 本来的活動とは無縁だから，そんなことに手を出す必要 なない」という人はほとんどいないであろう。それほど, 企業の社会的責任ないし社会貢献への評価は定着してき たといってよい。しかし，それは以前からずっと当然の こととして受け止められてきたわけではなかった。

小売業に打いても，企業の社会的責任ないし社会貢献 に対して注目が集まったことは過去に何度もあった4)。 しかし，近年でいえば，この問題がことさら注目を集め るようになったのは2004（平成 16）年であったといっ てよい。2000（平成 12）年に戦後, 日本の流通政策の中 心をなしてきた大規模小売店舗法が廃止され，改正都市 計画法, 中心市街地活性化法, 大規模小売店舗立地法加 らなる「まちづくり三法」体制がスタートするが，その 最初の見直しが行われたのがこの年であった。その見直 しの議論の舞台となった産業構造審議会流通部会と中小 企業政策審議会商業部会の合同会議では，大型店の社会 的責任について激しい議論が展開された。

ちょうどその当時, 2001（平成 13）年にマイカルが会 社更生法の申請を行い, 2004 （平成 16）年には戦後の日 本の流通革命を牽引してきたダイエーが経営破綻して産 業再生機構の支援要請を決定するなど，大型店の経営破 綻が相次いでいた。地域の中で核としての役割を果たし てきた大型店が，経営が困難であるとはいえ，突然姿を 消す。中心部に現れる広大な空き店舗や空き地は，中心 部の衰退を象銜するように後継店がないままに放置され， それが中心商店街の衰退感を一層高める。そのような事 例が各地に現れていた。

そのこともあって，この時点で特に注目を集めたのは， 大型店の撤退問題であった。小売業をめぐる環境の変化 は激しさを増していた。大型店は出店時にはそこでの長 期的な営業を企図していたとしても，途中のさまざまな 状況の中で撤退を余儀なくされることはもちろんある。 もとより，小売企業が好んで撤退するわけではないが, 大型店ともなればその撤退は地域商業に大きな影響を与 えずには扔かない。
地元の中小店にとってみれば，かつては大型店の出店 に異を唱えたものの，いったん大型店が出店すれば，彼 らは間違いなく地域の核となり，その大型店を中心とし て地域の新たな商業秩序が形成されるようになる。その 過程で，既存店の撤退などももちろんあるが，大型店の 退店は決してその出店前の状態への回帰ではありえない。 大型店が地域の中で一定の地歩を占めれば占めるほど, その撤退の影響は余計に大きくなる。中小小売店は，今 度は大型店の撤退に何らかの歯止めや制約を課すことを 求め始める。

しかし，いかに大型店の撤退が地域商業に大きな影響 を与えるからといって，それを国の法律などによって規 制することはできるはずもない。そうなれば，大型店が 早期に撤退の意向を地元に伝えると共に, 撤退の後に適 切な商業の参入を促すような努力を求める声が大きくな る。そして, その声は個々の企業にはもちろん, 業界, つまりは大型店の団体に向けられることになる。

そうした声に押されるように，国会でも閣僚から同様 の趣旨の発言が行われた。例えば, 二階俊博経済産業大 臣（当時）は2006（平成 18）年 5 月 10 日, 参議院本会 議に扔いて,「(業界ガイドラインについては) 自らの社 会的責任の一環として自主的に取り組むことが望ましい と考えております。経済産業省としても, 改正法案にお いて中心市街地活性化のための事業者の責務に関する訓 示規定を新設いたしました。この規定を踏まえ，事業者 が自主ガイドラインを作成するなど，その責務を果たす ように促してまいりたいと思っております。」と述べ5), 松あきら経済産業副大臣（当時）もまた，同年 5 月月 30 日, 参議院経済産業委員会において, 「大型店の撤退時の 対応，これは非常に事業者の対応は重要でございます。 やはりまちづくりに協力することは重要でありまして， 社会的責任の一環として自主的に取り組むことが私は望 ましいというふうに認識をいたしております。…経済産 業省といたしましては，改正法案に捛いて創設をいたし ました中心市街地活性化のための事業者の責務に関する 訓示規定を踏まえ，業界自主ガイドラインの策定を含め て社会的責任を果たすように促してまいります。」と述 ベた6)。

外部からの規制が行えないとはいえ，業界の側に「自 
主的」ガイドラインの設定を政府が求めたことになる。 これに呼応するように，日本チェーンストア協会「地域 商業者等との連携・協働のためのガイドライン」(2006 年 6 月), 日本百貨店協会「百貨店の地域貢献活動につ いて」(2006 年 11 月)，日本ショッピングセンター協会 「ショッピングセンターの地域貢献ガイドライン」(2007 年 1 月), 日本フランチャイズチェーン協会「『まちづく り』への連携・協力のガイドライン」(2007 年 5 月, 2013 年改定）が相次いで発表された。それぞれの団体のガイ ドラインの内容はそれぞれに個性的であり，まさに「自 主的」であって, 決して雛形があったわけでもなければ, 社会的責任や地域貢献の内容が退店問題に限定されたわ けでもなかった。しかし，それにもかかわらず，その制 定そのものが外部，それも政府の強い要請によるもので あったことは，当時の状況がまさにそれを必要としたも のであることを物語っている。

こうした大型店の地域貢献を求める動きが具体化する のは，2004（平成 16）年に東京都世田谷区が導入した 「商店街加入促進条例」が最初であったと見てよいだろ う。伝統的に地域で営業してきた中小小売商は各地域の 商店街や商店会連盟などの組織に加盟して，一定の地域 活動を行うのが常であった。それには大売り出しなどの 販促事業ももちろん含まれるが，ほとんどの場合，地域 のイベントなどの活動にも積極的に取り組んできた。こ れを中小店の純粋な販促活動と見れば，大型店がこれに 加入する「義務」はない。販促はそれぞれが独自の販売 戦略の一環として行うものだからである。しかし，実際 問題として，これらの活動には販促か地域活動かに明確 に二分できるものばかりではない。商店会などでは，街 路灯や防犯カメラを設置したり，地域の清掃活動を行う ほか，神社の祭礼などの催事などの地域活動に取り組む ことは決して少なくない。

大型店も地域の中で営業する以上, 商店会に加入して, こうした活動の一端を担うべきだというのが世田谷区が この条例を導入した背景であるが，すでに制定されてい た「産業振興基本条例」の中に，第 4 条第 2 項「商店街 において小売店等を営む者は，商店街の振興を図るため， その中心的な役割を果たす商店会への加入等により相互 に協力するよう努めるものとする。」抢よび第 4 条第 3
項「商店街において小売店等を営む者は, 当該商店街が 地域の核としてにぎわいと交流の場となるのに資する事 業を商店会が実施するときは，応分の負担等をすること により当該事業に協力するよう努めるものとする。」とい う条文追加したのであった。

もとより，これらは大型店の努力を促すものであって 強制力を伴うものではない。しかし，少なくとも自治体 の意志がこの形で明確に示されたことになる。行政の明 確な意志となれば，大型店もこれを無視することはでき ない。もとより, 加入するか否かは依然として大型店の 側に委ねられてはいるが，それによって実際に大型店の 加入は促進されるようになったという。

その後, この加入促進条例は他の自治体にも広がり, すでに 150 を超える自治体で導入されているという。大 型店の中には，いまや自治体から要請されるから加入す るというのではなく, 自ら進んで地域企業の一員として の「責務」を果たすという姿勢を明確にしているところ も現れている。

\section{III. 内的規範と外的規制}

小売業のほとんどが規模の小さな地元企業によって営 まれている間は, 地域貢献の問題は比較的シンプルであっ た。小売業であるから，業種が異なるだけではなく，商 店の歴史も違えば, 経営に対する考え方も異なる事業者 が集まるのはむしろ当然である。しかしそれでも，各経 営者はその地域で事業を営むと共に, 自らの生活を維持 するのが常であった。地域の商業者は，初めに商業者と して組織を形成するのではなく，その前に地域の人びと と共にそこに暮しの場をもった。多くの人びとはそこで 共に育ち，共に成長していく。そしてやがて，商業者と してまちに残る者があり，そのまちで消費者となる者が あり，あるいは独立してそのまちから巣立つ者があった。 他のまちから流入する者ももちろんあるが，彼らはすべ てそのまちで暮らすことが前提となっていた。

上で小売業の外部性を企業の活動でありながら市場で は取引の対象とならないもので，それでいて外部に対し てさまざまな影響をもつものとしたが，それらは上のよ 
うな状況では必ずしも意識的に取り組まれるものではな かった。商品を販売することは彼らがその地で暮らすた めの 1 つの手段であった。彼は商品を取り扱うことに よって地域の人びととつながり，人びとのニーズを満た した。やや極端に言えば，彼らはその地にいるからその 商品を販売するのであって，その商品を販売するために その地にいるのではない。

商業者にとって, 商品を販売することはもちろん重要 であるが，それと同様に店の前をきれいに掃除すること も，地域のイベントを盛り上げることも，商店街に賑わ いをもたらすことも，学校環境をよくすることも，みん な同様に大切なことであった。そこでは内部性と外部性 は，少なくとも意識の上では分かちがたく結びつき，一 体であった。いや，地域と共に歩むことは，その地に暮 らす者としての当然の生き方であり役割であった。まし てや，時間的にも経済的にも多少とも余裕があるとすれ ば，そうすることがごく自然であった。そこでは，外部 性を意識することをあえて「対外的視線」などと表現す ることもなく，小売店の行動の中に外部に対する影響が 当然のように組み込まれていた。

しかし，チェーン型の大型店が登場するようになると 事情は大きく変わってくる。大型店といっても, 単に規 模が大きくなるだけで，その地に単体で存在する場合に は，上とそれほど大きな変化は生まれなかった。商業者 にとっての主たる消費者はその地域の人びとであるから， 地域が豊かになることは購買力を豊かにすることであっ たし，快適な生活環境を創造するための努力は，自らに 対する評価となって跳ね返ってくることが期待された。 かつての地方都市における地元百貨店が典型的にそうで あったように，いわば地元の「名士」として，それ相応 の役割を果たすことが期待された。

しかし，チェーン店となると事情は異なってくる。 チェーン店にとって, そのまちに特別の思い入れがある わけではない。その地は全国にひろがる立地場所の 1 つ であり，商業を営む上での多くの立地場所の 1 つに過ぎ ない。経営者はその土地の暮らしとはもはや何の関係も 持たない。店長や従業員の多くはなおその地にかかわる 可能性はあるが, 彼らに意思決定の権限はない。その地 は純粋に企業が事業を営む場所となり，その事業の視点
から意思決定が行われるようになる。

そうなると, 市場で評価される内部性と, 評価されな い外部性が分離し始める。それまで深く意義を追求する ことなく当然のこととして行われていた対外的な「業務」 に意義が問われるようになる。なぜそうする必要がある のか, そうすることが事業のプラスの成果と結びつくの か, といった問いが意識的に投げかけられる。小売店が 事業であるという一点から見て, その問いそのものを否 定することはできない。そして, それに明確な答えが出 せなければ，その業務は本来的ではない業務，あるいは 非効率な業務として切り捨てられて行く。やや極端に言 えば，そうなるのが組織の論理であった ${ }^{7}$ 。

外部性は意識して議論され, そして意味がなければ切 り捨てられる。そして, その意味の有無を判断する基準 は「市場の論理」であり, 究極のところそれが地域の消 費者に受け入れられるか否かである。買うのは先の消費 者と同じ消費者には違いないが, 彼らは商品を買うので あって, 残余の外部性を買うわけではない。外部性を切 り離し,「本来の」商品だけが効率的に提供され, それを 消費者が支持するようになる。そうなれば，小売業はま すます効率性を求め, 商品の販売のみを強く意識するよ うになる。対外的視線はもはや自然に入り达むようなも のではなく，むしろ意識的に削ぎ落されるものとなって いく

ここでの議論を規制と規範の文脈において，小売業が 小規模であったときには対外的視線はいわばそれぞれの 内的規範として共有され，ルールとして維持されてきた と言い直してもよい。それは他の誰かから指摘されるま でもなく, 当然のこととしてそれぞれの行為者の中の規 範であった。共有された規範はその内部に属する者にとっ ては強力な行動指針となるが，外部者にとってはしばし ば意味の不明な単なる慣習のように見える。しかも，明 文化されず，伝承によって継承されてきたものは，その 意味を曖昧にし，解釈の余地を与える。内的規範による ルールの維持は決して安定的でもなければ強固でも ない8)。

例えば, 地元で営業する者にとって, 地元の経済商工 団体に所属し, 応分の負担を行いながら地域の活性化に 貢献するというのは，いわば暗黙のルールであった。も 
とより，全員がそれを誠実に遵守したなどとは言えない。 しかし，少なくともそれを遵守することの意義に疑問を さしはさむ余地はなく，それに十分な協力ができない場 合には，そのことに対する負い目を感じるのが普通であっ た。地域活動に取り組めない人びとは積極的に地域活動 に取り組む人びとにある種の敬意を表し，それが後者の 人びとの社会的地位を高めた。多くの商業者がそうした 規範を共有している限り，地域経済団体への参加は打押 よそのルールとして受け入れられ，運営されることがで きた。

しかし，多くのチェーン型の大型店にとってはそうで はなかった。外部から入ってくる彼等にとって，それは いかなる意味でも規範となり得るものではなかった。東 京都世田谷区から始まった商店街加入促進条例はその点 を補完するものにほかならない。それはその必要性を認 めなかった企業からすれば，明らかに外部からの規制で あり，拘束であるに違いない。しかし，それは単なる外 部からの規制ではなく，もともと地元の商店にとっては 内的な規範であったものを確認し，公式化したものにほ かならない。

こうした外的規制の中でも，法律や条例は議会の審議 を経たものであるだけに，その公式性は格段に高くなる が，反面でその公式性がその規制の受容可能性を高める。 そのことは，その規制内容が地元団体からの単なる要請 である場合と比べれば直ちに明らかであろう。要請され る内容に違いがあるわけではない。しかし，いまやそれ は地元の一団体の要請ではなく, 行政の要請であり, 市 民を代表する議会の要請となっている。最も公式性の高 い法律や条例は遵守すべきだというのも私たちの規範に ほかならないが，その規範が条例の受容可能性を高める。 「それが自治体の意志であるのなら」として，この条例に よって加入企業が増加したというのはそのことを示して いる。

\section{IV．小売業の社会貢献活動}

こうした流れを強調すれば，大型店が伝統的に社会的 責任や社会貢献に対して消極的な姿勢を示していたよう
にも受け止められるかもしれない。しかし，そう言うの がここでの本意ではない。大型店はもともとその「地域 の企業」ではないとしても，その「地域で営業する企業」 であることに変わりはない。確かに, 大型店, 特にチェー ン店にとっては特定の地域は決定的に重要な地域でな く，多くの立地可能な地域の 1 つに過ぎないのだとして も，立地可能な地域は無限に存在するわけではない。そ れだけではない。出店するにしろ退店するにしろ，それ には莫大な費用が必要なのであり，経済学が想定するよ うな移動費用ゼロの世界で行動しているわけでは決して ない。その意味では，大型店もまた小売業として，その 地域に根を下ろすことを目指してきたはずであった。

問題は何をもって「企業の社会貢献」と見なすかにあっ た。先に指摘した 2004（平成 16）年の合同会議の席で 問題になったのも，実はその点であったといってよい。 地域の中小店は大型店に社会貢献を求めるのに対して, 大型店は法令順守を含めて社会的責任は果たしていると 考えていた。では一体, 小売企業の社会的責任ないし社 会貢献と何なのか。以下，このことを考えるためにも， さしあたり企業の社会貢献活動を小売業の「本業」に直 接かかわるものと，本来の企業活動とは直接関係をもな いものに分けて考えることから始めよう。もちろん，こ の両者は常に明確に区別できるものではないが，そのこ とはそれほど重要な問題ではない。

例えば，まだ大規模小売店舗法が存在した時代ではあ るが，出店に際して社会貢献のあり方を問われたとき， 大型店の関係者はしばしば「良い品物を安く, 安定して 販売することで地域の皆様に貢献します」といった趣旨 の説明を繰り返していた。確かに, それも社会貢献活動 でないとは言えない。しかし, 商品の安定供給はいわば 小売業としての「本来的」な事業のあり方そのものであ り，市場において評価されるものにほかならない。もと もと企業は社会に対して何らかの便益を提供し，その見 返りに給付を受けるものであることを考えれば，それは あえて「社会貢献」として強調するまでもない，小売業 としての当然の事業内容だということになるはずである。

あるいは，「地域に雇用機会を提供します」というの も，これとほとんど同じことが言える。確かに，地域経 済を活性化するためには地域の中に確かな雇用機会，あ 
るいは就業の機会がなければならず，雇用は地域に活力 をもたらす 1 つ重要な機会であることは間違いない。 しかし，逆に企業の側から言えば，雇用を確保すること なしには企業活動を継続することはできない。その意味 では，雇用機会を提供するというのは，企業がそこで事 業を継続するというのとほとんど同義なのである ${ }^{9)}$ 。深 夜営業を行うチェーン店が深夜に点灯するのも, これと 同様に考えてよい。確かにそれによって, 地域住民にとっ ての安心・安全は高まる。そのことの意義は確かに大き いが，それは深夜に営業することの必然的な結果であり， あえて「社会貢献」として強調することではないだろう。

こうした企業の本来の活動の対極にある取り組みとし ては, メセナやフィランソロピー, 各種の寄付などをそ の典型として挙げることができる。企業はそれぞれに独 自のドメインの中で行動し，利益をあげる。その利益は 広く社会からの支持で得られたものであるが, 今度はそ の一部を広く社会に還元しょうというのである。その還 元先は企業の本来的な活動に縛られる理由はない。地球 規模で発生している人権問題であってもいいし，国際紛 争の解決やその被害者救済であってもかまわない。ある いは，災害時の被災地支援などもこれに含めてよい。直 接的な活動だけではなく，それらを実践する機関や団体 への寄付などを通しての間接的な支援もこれに該当する。

さらに, これに各種のスポーツや芸術イベントなどへ のスポンサーシップを加えることもできる。この場合に は，スポーツやイベントの支援そのものだけではなく， それらを支援していることを外部に明示し，それによっ て共感を得ようとする狙いがもちろん含まれる。その意 味で, それは企業の広告・宣伝の一環としての側面が含 まれるが，それでもそれなしにはイベントそのものが成 り立たないのだから，これを社会貢献と理解することは できるだろう。さらには，これに植樹などを含めて考え ることもできる。

これらはいずれも確かに企業の社会貢献に違いない。 しかし, それらは企業の本来的活動とかけ離れた分野で, しかも地域ないし場所を特定することなく行われるもの である。企業の事業活動から切り離され, 立地の縛りも なくなるとなれば, 必要なのは資金だけとなり，一定の 予算さえ確保すれば「自由に」行うことができる。いま,
小売業が特定の地域, 特に小売店舗が立地するその地域 を中心に行われる社会貢献を特に「地域貢献」と呼ぶと すれば,これらの活動は社会貢献に違いはないが, 決し て地域貢献であるとは言えないことになる。そして, 先 の合同会議においても中小小売業者たちが求めたのはこ の意味での地域貢献だったのである。

\section{V. 小売業の地域貢献とコミュニティ}

小売企業はいまやさまざまな社会貢献, 地域貢献活動 に取り組んでいる。その最も代表的なものとして, 2017 (平成 29）年 9 月, 災害対策基本法に基づく指定公共機 関に小売業の 7 法人 ${ }^{10)}$ が追加されたことを見ても明らか であろう。それによって，これらの企業は災害時におい て, 地方公共団体等からの要請に基づいて, 支援物資の 調達，迅速な供給を担うこととなった。2011（平成 23） 年 3 月に発生した東日本大震災は私たちの防災に対する 考え方の決定的な変化を迫ったが, これはそれ以降, 各 企業が自治体との間に締結してきた「包括提携協定」な どによる支援体制が評価されてのことであり，それによっ て小売業はまさに「公益的事業を行うもの」として認定 されたこととなる。その包括提携協定はまだ増加中であ るが, 例えばイオンの場合, すでにほとんどすべての都 道府県と政令市をカバーするまでになっている。

その他にも小売企業はそれぞれの視点から，実に様々 な地域貢献活動を行っている。その活動のひろがりは地 域の中小商店がまったく及ぶことのできない範囲に達し ている。それだけではない。かつてはチェーン店といえ ば本部の権限が強く, 本部の指示に従って各店が行動す るものと考える傾向が強かった。そこでは各店の独自性 は極小化され，地域の独自性が商品や店舗運営に反映さ れることはほとんどなかった。しかし，いま店長の権限 を大幅に認め, 地域の個性に見合った店舗づくりに取り 組むチェーン店が増えていることは特に強調しておくに 值する。

問題はそれにもかかわらず, 地域の側からチェーン型 の大型店に対して, なお地域貢献を求める要望が出され るのはなぜかという点にある。考えられる原因はいくつ 
かある。第 1 は単純に大型店がどのような事業を行って いるかが分からない場合である。もちろん，大型店は情 報発信をするだろう。しかし，それは地域の人びとに正 しく受け止まられるとは限らない。第 2 は大型店の活動 がその地域に向けられず，広域の外部に向けられること が多い点である。だから価值がないというのではもちろ んない。しかし，地域の人びとからすれば，それは遠い 世界のことのように思え，それだけ関心が低くなる可能 性がある。第 3 には大型店の地域活動の多くはほとんど その企業単独で行われており, 他の事業者, 特にその地 元の関係者を巻き込むことが少ない。そのことが地元の 人びとのその事業への関心を引き付ける力が弱くなる。

この最後の点について，もう少し考える。近年，「共 創」なる概念が多用されるようになったが，それが意味 するところは，商品にしろサービスにしろ，提供者側と 需要者側を峻別し，提供者がいかに優れたものを，いか に効率的に提供するかという視点から脱して，提供者と 需要者が相互に関与しながら価值をつくり上げていこう ということであろう11)。そうすることによって，単に内 容的に見て需要者の満足度の高い価值が提供されるとい うだけではなく，その価値を創り出す過程そのものが重 要な意味を持つようになる。

このことが特に強調されるのは, 地域商業の関心が「ま ちづくり」に大きく傾斜してきたことと密接に関連する。 「まちづくり」の意味するところは必ずしも明確ではない が，小売業の世界ではほぼ売業が営まれてきた都市空 間における地域の人びとの生活の支え合いを意味するも のとして理解されている。そこでは小売業は重要なプレ イヤーではあるが，そこには多くの関係者が同時に参加 する。小売業起点とはいえ，小売業が一方的に何かを提 供して終わるのではない。まさに「共創」する世界がそ こにある。

あるいは, 自助, 公助に対して「共助」の重要性が強 調されるのもほぼ同じ文脈である。私たちの身の回りに 発生するさまざまな事柄をすべて自らの力で解決するこ とはもちろんできない。だからといって，それを行政が 担うことはもはやできない。行政の負担力の低下が顕著 となる中で，住民自身による支え合いに期待がかかるこ ととならざるを得ない 12 。
いま，地域小売業における最大の関心はこの「まちづ くり」に置かれている。その背景をここで詳述すること はできないが，かつては商業活動そのものと切り離しが たく結びついていた外部性が切り離され，しかも伝統的 にまちを支えてきた商店の商業力が低下することによっ て，外部性そのものが希薄化せざるを得なくなった。そ こから，今一度商業の外部性に議論の焦点を当てること によって，まちなかに商空間を中心とした暮らしの場， 交流の場を取り戻そうというのである。ほほ 1980 年代 後半期に始まったこの動きは, 2000 年以降本格化しなが ら，現在さらに深化しょうとしている。

商店街を中心としたまちなかの商店によるこうしたま ちづくりの活動は，今やきわめて多様な方向に展開して いる。地域の安心 - 安全の問題に始まって, 高齢化社会 と子育て支援への対応，さまざまな地域資源を活用した イベントやアートの創造など実に多彩で, 単に地域問題 を解決するというだけではなく，地域に新しい価値を創 造しようというものもある。さらに，それらは担い手と して学生たちを巻き込むことで, 多世代の取り組みの発 展しているものもある13)。こうしたまちなかでの活動は かつては商業者達の自発的活動として行われていたが, 近年ではその活動の範囲が広がり, 全体としてのマネジ メントする必要性が高まったこともあって，専門的な タウン・マネージャーを採用するところも多くなって いる14)。

こうした取り組みを見れば，商店街を中心にまちなか で現在展開されているのは, かつての販促イベントや大 売り出しといったものとは性格を異にしたものであるこ とが理解できるだろう。単に集客イベントによって人を 引き付けようというのではない。もっと豊かな地域の人 びとの交わりと交流の場の創造であり, 地域の人びとを 広く卷き込んで展開される地域価值の創造である。その 場としてまちなかが選ばれるのは，そこが多くの場合都 市の中心としての歴史をもち，多くのストックをもち， 人びとの記憶の空間であるからである。商業者はそこで 活動するものとして，当然のようにその取り組みに中に 巻き达まれ，そしてその担い手となっていく。

商業者が担い手となるのだから，当然にそこに事業と しての収益が発生しなければならない。全国商店街振興 
組合連合会の副理事長, 阿部眞一（長野県岩村田本通商 店街振興組合理事長) は「右手にそろばん, 左手にコミュ ニテイ」と表現している ${ }^{15)}$ 。個々の活動 1 つ1つが収益 事業となるかどうかは別として，そうした取り組みが地 域の人びとに支持され，それが日常の商業活動に還元し てくる必要はある。そのことを強調すれば，たちまち「衣 の下から鎧」だいう指摘が起こりうる。しかし，こうし た地域の活動は誰が行おうと, 必ず一定の費用支出を伴 うのであり，それを特定の人びとのボランティアによっ て長期的に維持していくことは絶望的に難しい。むしろ, 地域の商業者たちの取り組みよって小さな収益の循環を 発生させながら, 地元の人たちが共に担っていくことこ そが，あるべき姿だというべきなのだろう。

但し, その場合, 担い手となる組織は従来の商店街組 織と一致するとは限らない。商店街組織は比較的狭い工 リアを確定し，その中での共同事業を行ってきたが，ま ちづくりとなれば, 対象範囲は広がり, 事業者の範囲も 広がる。新たに参入する事業者もそのエリア内に収まる ことなく, 周辺に展開する。したがって, 彼らを巻き込 むにしても，その組織としての受け血は既存の商店街組

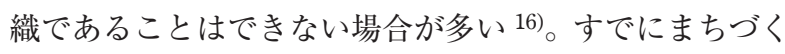
り会社を立ち上げたり，NPO 法人を立ち上げるなど，新 たな組織づくりの模索は始まっているが，そうした受け 入れ態勢をどのように整備するかは，今後の課題となる だろう。

そして、いま地元の商業者たちがチェーン型の大型店 に求めているのは, こうしたまちづくり活動の中に共に 参加して欲しいということである。既に行われている包 括協定も植樹もすべては貴重な地域貢献である。しかし, その上でもう一段, こうした地元の取り組みと共同歩調 をとることはできないか。そうすることによって，大型 店が真にその地域に根ざした企業となることができるは ずである。

\section{VI. むすび}

小売業に社会的責任を求め, 社会貢献や地域貢献を求 めるのは，小売業に対する地域からの期待である。期待
の内容はもちろん時代とともに変わる。高度成長期には 比較的小さかったその声は, やがて大きな流れとなって 表現されるようになってきた。「責任」といい，「貢献」 といい，本来それらは小売業の自主的な取り組みとして 行われるべきものである。しかし，業者側での自発的な 取り組みが遅れるとき, 外部からの要請が具体的に姿を 現す。本稿では商店街加入促進条例にその典型例を求め たが，それは小売企業への大きな期待にほかならな かった。

外部からの期待はこの場合であれば「条例」という形 での外的規制として現れた。それは形式的に見れば強制 力をもつものではなかったが，それでもそれは公式性の 高い規制として, 多くの企業にとっては外的規制と映っ たはずである。しかし，それを受け入れて行動するうち に, やがてその外的規制が自らの内なる規範として受け 入れられていくようになる。まさに「しなければならな いことを，したいと欲するようになる ${ }^{17) 」 の て ゙ あ り ， そ ~}$ の限りでこうした外的規制にも十分な役割があったとい うことはできる。

そして今, 地域商業の現場では「まちづくり」が強調 されるようになってきた。特に店舗型の商業者は単に商 品を販売するだけではなく, 同時に意識的か無意識的か を問わず，地域社会に対してさまざまな働きかけを行っ ている。小売業の外部性と呼んだそれは，かつてはほと んど無意識的の内に事業活動の中に取り込まれていた。 チェーン型の大型店の登場によって失われかけたその側 面をもう一度呼び戻そうとする期待がある。今, 地域商 業の現場では, 多くの市民や学生たちを卷き込みながら， さまざまな活動が行われている。その詳細はここではふ れられないが, その隊列の中に大型店に参加して欲しい, その期待が今, 大型店に寄せられる地域貢献の最も重要 な側面となっている。

最後に，1つの逸話をもって本稿の結びとしたい。高 度成長期,「流通革命」という言葉がまだ現実的な害感を もって受け止められていた時代である。繁盛店を生み出 すための全国的なセミナーが多く開かれていた。そこに は小売店としての経営を見直し, 経営を近代化しょうと いう意欲に燃えた多くの小売商が全国から集まった。そ の席で，こんな話が実話として伝えられている。壇上か 
ら講師が「この中に，商店街の理事長，PTA や町内会， ロータリークラブの役員などをしている人はいますか？」 と声をかける。何人かが意気揚々と手を挙げると，講師 はすかさず「あなたの店は潰れます。すぐにそんなこと はやめなさい。と宣言したという。

もちろん, この講師の発言の意図を改めて解説する必 要はないだろう。小売業をめぐる環境が大きく変化して いるとき，大切なのは消費者に対して何を，どのように 提供するかであって，それをこそ第 1 に考えるべきであ り，それ以外のいわば自己満足にも見える「地域活動」 などにうつつを抜かすべきではない。それでは「地域の 名士」になるのが関の山であるが，そんなことに満足し ては小売業として成長できない。それは小売業としての 成長を阻害することにしかならない。

おそらくそれは非常なショックをもって受け止められ たことだろう。そして，その言葉を聞いて，それに同調 した人達は「企業家商人」の道を歩んだ。彼らは自分の 商売を見つめ, その革新に人生を賭けた。彼らが追求し たのはもちろん「消費者利益」であった。しかし，その 消費者はいわば経済学の教科書の中に登場するような, 商品だけを評価し，地域を意識しない「無国籍」な消費 者であった。

しかし，それに同調できない人達は，決して地域活動 をやめようとはしなかった。彼らは地域の中で活動し, 地域の人びとに向き合い，地域を支えてきた。彼らは「街 商人」であった ${ }^{18)}$ 。彼らはまちにこだわり，自分たちが 小売業を営む場をつくろうとした。彼等の目線も消費者 に向けられたが，彼らが見た消費者は無国籍の消費者で はなく，その地域の中で人びとと共に生活を営む，その 地域の消費者であった。

ここで比喻的に表現した無国籍の消費者と地域の消費 者は決して別個の人格であるわけではない。それぞれが 濃淡の差こそあれ，私たちの中に混然一体となって含ま れている。効率化を訴える小売業の働きかけに応えて消 費者はその無国籍性を表面化させたが，しかし決して純 粋な無国籍な消費者となることはなかった。効率性を求 めながらも，消費者はなお地域の中で暮らし続けた。そ うした消費者の地域性に応えながら，その側面に強く働 きかけることによって，消費者にも地域の人びととして
まちづくりへの参画を求める。そうすることによって真 の共創を実現することができる。その輪の中に，チェー ン型の大型店にも参加して欲しいという期待がある。

高度成長期から時代は大きく変化した。小売業は対外 的視線をもって，地域に溶け込むことが当たり前のよう になっている。労働市場も緊迫し, パート労働者も思う ように集まらなくなりつつある。優秀なパート労働者を 確保するためにも，地域に根ざし，地域の人びとに支持 されなければならない。いまやかの講師は前言を撤回し てこういうはずである。「地域に支持されなければ，あな たの店は潰れます。」

注

1）流通政策は振興政策と調整政策の二本立てで理解するのが 普通であった。しかし，2000（平成 12）年の大店法の廃止 はその理解に大きな疑問を投げかけた。むしろ，流通政策 は効率化政策と地域政策の二本立てとして理解されるべき であった。この点，詳しくは Ishihara（2011）参照。

2）例えば 1970 年代の POS 導入期がそうであった。業界の理 解が容易に得られない中で，行政主導で導入が図られた。 Nikkei Ryutsu Shinbun (1976)。あわせて, Hashimoto (1998) 参照。

3） Ishihara (2006), Ishihara（2009）参照。

4) Kuramitsu (1991) 参照。

5) Kanpou Gougai Dai 164 kai Kokkai Sangiin Kaigiroku, No. 22 (2006)。

6) Dai 164 kai Sangiin Keizaisangyo Iinkai Kaigiroku, No. 16 (2003)。

7）もちろん，一口にチェーン店といっても，いわゆるレギュ ラー・チェーンばかりではない。確かに，ボランタリー・ チェーンやフランチャイズ・チェーンの場合には, 地元の 経営者が店舗のオーナーとなることが多く，地元への思い 入れもまだかなり残っていることは期待できる。しかし， これらの場合にも，本部の方針の各店への「拘束」がレギュ ラー・チェーンの場合とほぼ変わらず，地元のオーナーの 自由裁量の余地はそれほど大きくない場合が少なくない。

8) Hart (1961)。

9）この新たな雇用機会の創出という問題には，2つの但し書 きが必要である。1つは大型店が雇用機会を生み出す反面 で，例えば商店街等で雇用ないし就業の機会が奪われてい ないかという点である。明確な因果関係を特定することは できないが, 長期的に見て, 大型店の進出が中小小売商の 事業機会を奪ったこと自体は, 事実の問題としてほぼ間違 いないだろう。そうだとすれば，雇用機会の創出はその点 を差し引いて評価される必要がある。もう1つは雇用の質 である。大型店が地域にもたらす雇用機会の圧倒的な割合 はパートなどの非正規労㗢である。地域によってはこうし た時間限定の非正規労働にこそ労働需要があるという事情 は確かに存在する。しかし，この雇用の質を問わなければ, 極端な場合, いわゆる「ブラック企業」までもが雇用機会 
を提供しているということにもなりかねない点には，注意 が必要である。

10）（株）イトーヨーカ堂，イオン（株），ユニー（株），(株） セブンーイレブン・ジャパン，(株）ローソン，（株）ファミ リーマート, (株) セブン\&アイ・ホールディングズの 7 社。

11) Wada (2002)。

12) Ishihara (2016)。

13) Ishihara and Watanabe (2018)。

14）Ishihara（2013）。なお 2016（平成 28）年 12 月には「一般 社団法人全国タウンマネージャー協会」が設立されている。

15) Keizaisangyosyo Syoumu Ryutsu Hoan Group Chushin Shigaichi Kasseikashitu (2013)

16）例えば， Kazetani (2005) Toshin niokeru aratana shougyouchino seisei, in Ishihara and Kato (2005), Sato (2003) Shizen hasseigata sakariba no keisei to henyo no bunseki, in Kato (2003)。

17) Fromm (1941)。

18）Doi（2002）。「企業家商人」と「街商人」については, Ishihara（2006）を参照のこと。

\section{References}

Dai 164 kai Sangiin Keizaisangyou Iinkai Kaigiroku Dai 16 gou. (May 30, 2003). (『第 164 回参議院経済産業委員会会議録第 16 号』平成 15 年 5 月 30 日, 30 頁) (In Japanese)

Doi, T. (2002). TENJIN san no Syoutengai. Osaka: Toho Publishers. （土井年樹（2002）。『天神さんの商店街』東方出版）(In Japanese)

Fromm, E. (1941). Escape from freedom. Now York: Farrar \& Rinehart.（日高六郎（訳）（1965）、『自由からの逃走』東京 創元社)

Hart, L. A. (1961). The concept of low. Oxford Univ. Press.（矢崎光 图外（訳）（1976）。『法の概念』みすず書房）

Hashimoto, K. (1998). Bar cord heno cyousen-Asano Kyousuke to sono jidai. Tokyo: Nihonkeizai Shinbunsha. (『バーコードへの 挑戦一浅野恭右とその時代』）(in Japanese)

Ishihara, T. (2006). Kourigyou no gaibusei to machizukuri. Tokyo: Yuhikaku.（石原武政（2006）。『売業の外部性とまちづく り』有斐閣）(In Japanese)

Ishihara, T. (2009). Ryutsu kenkyu ni okeru bussyousei. Sanken Ronsyu, 36, 3-11. (石原武政 (2009)。「流通研究に打ける物 象性」『産研論集』36, 3-11.) (In Japanese)

Ishihara, T. (2011). Chiiki syogyo seisaku no keifu. Journal of Business Administration, 58(2), 55-89. (石原武政 (2011). 「地域商業政策の系譜」『商学論究』58(2), 55-89.) (In Japanese)

Ishihara, T. (ed.) (2013). Town-Manager. Kyoto: Gakugei Publishers.（石原武政（編）（2013）。『タウン・マネー ジャー』学芸出版社）(In Japanese)

Ishihara, T. (2016). "Kourigyou ga chiiki ni nezasu" to iukoto no imi. Izumiya Souken, 107, 6-13.（石原武政（2006）。「小売 業が地域に根ざす』ということの意味」『イズミヤ総研』 107, 6-13.) (In Japanese)

Ishihara, T., \& Kato, T. (eds.) (2005). Syougyo-machizukuri network. Kyoto: Minerva Shobo.（石原武政・加藤司（編）（2005）.
『商業・まちづくりネットワーク』ミネルヴァ書房) (In Japanese)

Ishihara, T., \& Watanabe, T. (eds.) (2018). Kourigyou kiten no machidukuri. Tokyo: Sekigakusya. (石原武政・渡辺達朗（編） (2018).『小売業起点のまちづくり』碩学舎) (In Japanese)

Kanpou Gougai Dai 164 kai Kokkai Sangiin Kaigiroku Dai 22 gou. (May 10, 2006). (『官報号外第 164 回国会参議院会議録第 22 号』平成 18 年 5 月 10 日， 7 頁）(In Japanese)

Kato, T. (ed). (2003). Ryutsu riron no toushiryoku. Tokyo: Chikura Syobo.（加藤司（編）（2003）。『流通理論の透視力』千倉書 房) (In Japanese)

Kazetani, M. (2005). Toshin niokeru aratana shougyouchino seisei, in Ishihara and Kato (2005).

Keizaisangyosyo Syoumu Ryutsu Hoan Group Chushin Shigaichi Kasseikashitu. (2013). Sukina machi de cyousen shi tuzukeru. (経済産業省商務流通保安グループ中心市街地活性化室 （2013）。『好きなまちで挑戦し続ける』p. 58）(In Japanese)

Kuramitsu, H. (1991). Keiei kankaku kakumei. Tokyo: Toyo Keizai Inc.（倉光弘已（1991）。『経営感覚革命』東洋経済新報社) (In Japanese)

Nikkei Ryutsu Shinbun (1976). POS wo syuyakuni: Kuruka dainino ryutsu kakumei. 1976.9.9. (日経流通新聞（1976)。「POS を 主役に/来るか第二の流通革命」1976 年 9 月 9 日) (in Japanese)

Wada, M. (2002). Brand kachi kyousou. Tokyo: Doubunkan Publishers. (和田充夫 (2002). 『ブランド価值共創』同文 舘出版）(In Japanese)

\section{石原 武政（いしはら たけまさ）}

大阪市立大学名誉教授，商学博士（大阪市立大学） 1969 年 神戸大学大学院経営学研究科博士課程退学。 大阪市立大学商学部, 関西学院大学商学部, 流通科学大学 商学部の各教授を経て 2017 年退職。

主著『マーケティング競争の構造』(千倉書房，1982 年), 『商業組織の内部編成』(千倉書房, 2000 年), 『小売業の外 部性とまちづくり』有斐閣, 2006 年など。 